\title{
Epileptic seizure? Certainly uncertain
}

\author{
Sven P. Heinrich $(\mathbb{D} \cdot$ Hansjürgen Agostini
}

Received: 6 April 2021 / Accepted: 15 April 2021/Published online: 30 April 2021

(C) The Author(s) 2021

\section{Dear Editor,}

We appreciate the cautionary remarks by Hamilton and Zuberi [1] in response to our recent case report [2]. They express concerns that the presented case had been labelled as "epileptic" in the absence of sufficient evidence.

Indeed, the exact nature of the event is unclear. The circumstances prevented a direct observation of the development of symptoms, and we had no influence on the subsequent examinations that were performed routinely in the neuropediatric unit. As per the patient files, no EEG was performed.

Given this uncertainty, we carefully avoided using "epilepsy" or "epileptic" when describing the event itself. Of course, we could not avoid using these terms when providing a larger context, referring to the literature, or addressing the patient history. We regret that this may have caused the impression that we were certain about the classification of the event.

This reply refers to the comment available online at https://doi. org/10.1007/s10633-021-09838-8.

S. P. Heinrich $(\bowtie) \cdot H$. Agostini

Eye Center, Medical Center, University of Freiburg,

Killianstr. 5, 79106 Freiburg, Germany

e-mail: sven.heinrich@uni-freiburg.de

S. P. Heinrich · H. Agostini

Faculty of Medicine, University of Freiburg, Freiburg,

Germany
We are grateful to Hamilton and Zuberi for pointing us to the CEVnet archive.

Funding Open Access funding enabled and organized by Projekt DEAL. No other funding was received.

\section{Compliance with ethical standards}

Conflict of interest The authors declare that they have no conflict of interest.

Statement of human rights All procedures performed in studies involving human participants were in accordance with the ethical standards of the institutional and/or national research committee and with the 1964 Declaration of Helsinki and its later amendments or comparable ethical standards.

Statement on the welfare of animals This letter does not contain any studies with animals performed by any of the authors.

Informed consent No procedures were specifically performed for this letter. See original case report [2] for further details.

Open Access This article is licensed under a Creative Commons Attribution 4.0 International License, which permits use, sharing, adaptation, distribution and reproduction in any medium or format, as long as you give appropriate credit to the original author(s) and the source, provide a link to the Creative Commons licence, and indicate if changes were made. The images or other third party material in this article are included in the article's Creative Commons licence, unless indicated otherwise in a credit line to the material. If material is not included in the article's Creative Commons licence and your intended use is not permitted by statutory regulation or exceeds 
the permitted use, you will need to obtain permission directly from the copyright holder. To view a copy of this licence, visit http://creativecommons.org/licenses/by/4.0/.

\section{References}

1. Hamilton R, Zuberi SM Insufficient evidence to support the clinical diagnosis of an epileptic seizure. Doc Ophthalmol. https://doi.org/10.1007/s10633-021-09838-8
2. Heinrich SP, Agostini H (2020) Seizure triggered by flicker electroretinogram in a patient with no history of epilepsy. Doc Ophthalmol. https://doi.org/10.1007/s10633-02009813-9

Publisher's Note Springer Nature remains neutral with regard to jurisdictional claims in published maps and institutional affiliations. 